Reprod. Nutr. Dévelop., 1985, 25 (1 A), 39-48.

\title{
Influence of photoperiod on the time of birth in the rat. IV. Effects of an imposed feeding rhythm
}

\author{
M. J. BOSC, Agnès NICOLLE
}

Station de Physiologie de la Reproduction, I.N.R.A., Nouzilly 37380, Monnaie, France.

Summary. In order to study the respective effects of photoperiod and feeding rhythm on the time of birth in rats, the onset of fetus expulsion was determined in six experimental groups. Under the standard light regime (14L-10D ; lights-on at 6 a.m.), rats caged alone or in threes and fed ad libitum (groups $\mathrm{C}$ and $3 \mathrm{C}$ ) gave birth over two preferential periods, the first during the late light phase of day 22 of gestation and the second during the early light phase of day 23 . Under the same conditions, rats fed during a restricted period (from 9 a.m. to 11 a.m.) from day 8 of gestation (groups PF and 3PF) gave birth during a single period, starting just before and spreading over the first half of the night separating the last two days of gestation. The number of rats per cage affected birth distribution slightly, but an inverse effect was observed between the feeding regime and the social group constituted by mating (group $3 \mathrm{C}$ vs $3 \mathrm{PF}$ ). Most births occurred after lights-on at day 23 of gestation when the rats were caged alone, fed ad libitum and submitted to a progressive shift in the light phase (group BC). This shift was realized by daily advancing dawn and dusk every day by $15 \mathrm{~min}$ from day 8 of gestation. Under these conditions, food restriction from 9 a.m. to 11 a.m. (group BC-PF) resulted in an intermediate distribution between groups $B C$ and PF. The data show that time of birth in rats can be modulated by two different biological entrainers, photoperiod and feeding rhythm and that time of birth, in a given case, is determined by the interactions between these two factors.

\section{Introduction.}

Circadian variations in the probability of birth reported for mammals have not only been related to the light/dark cycle but also to other environmental cues such as temperature, management and living conditions (Bosc, 1980). However, experimental works on the association between environment and time of birth have been essentially devoted to studies on the effects of photoperiod, and most have been carried out on pregnant rats (Mitchell and Yochim, 1970 ; Plaut et al., 1970 ; Lincoln and Porter, 1976 ; Bosc and Nicolle, 1980a, b ; 1982).

The length of gestation in rats can be modified by treatments which affect adrenal secretions (Parvez et al., 1972 ; Bosc and Nicolle, 1980a ; Klepac, 1981), and the ability of light to control the circadian aspects of the secretion of corticosteroid and corticotropin is well documented (Szafarczyk et al., 1971; Krieger, 1974 ; Dupouy and Cohen, 1975 ; Ixart et al., 1977 ; Szafarczyk et al., 
1980 ; Pechinot and Cohen, 1983). This is also true of the effects of feeding rhythms (Johnson and Levine, 1973 ; Krieger, 1974 ; Moberg et al., 1975 ; Krieger et al., 1977 ; Obled et al., 1977 ; Takahashi et al., 1977 ; Morimoto et al., 1979 ; Itoh et al., 1980; Kato et al., 1980; Miyabo et al., 1980). Periodic food distribution has often been utilized in rats as a biological entrainer. By a combination of imposed food and water distribution and ambiant light/dark cycles, Edmonds and Adler (1977a, b) have shown that the period of food access during the illuminated portion of the light/dark cycle is a more potent entrainer of wheel-running activity than photic cues. This periodic presentation of food and water at a determined time daily also entrains a feeding rhythm (Obled et al., 1977 ; Morimoto et al., 1979 ; Miyabo et al., 1980) which differs from that of animals fed ad libitum (Besch, 1970 ; Obled et al., 1975, 1977) since the latter usually consume their food during the nocturnal period of activity.

As several biological entrainers may be implicated in the control of birth time, we studied the effects of a non-photoperiodic cue on the timing of birth in rats. A comparison has been drawn between an imposed feeding rhythm and an ad libitum regime, and we also used two photoperiods to determine any possible interactions between feeding and photoperiod. To attempt to amplify response to the feeding treatments, the responses of isolated rats have been compared with those of grouped animals.

\section{Material and methods.}

Animals. - We used rats originating from strain $\mathrm{O} 3$ of our colony. Their management has been described previously (Bosc and Nicolle, 1980a). Briefly, they were kept in constant-temperature rooms under a standard light regime of $14 \mathrm{~h}$ of light and $10 \mathrm{~h}$ of darkness (14L-10D) with lights-on from 6 a.m. to $8 \mathrm{p} . \mathrm{m}$. At 70 to 90 days of age, the females were caged with a male for 3 successive days. At mating (day 1 of pregnancy), confirmed by the presence of spermatozoa in vaginal smears, they were allocated to one of six experimental groups. Two mating sessions were necessary to complete all the groups, and each female was allowed a maximum of two pregnancies.

Experimental groups. - The treatments were: photoperiod, timing of feeding, and the number of rats per box $(45 \times 30 \times 20 \mathrm{~cm})$ (table 1). In two

TABLE 1

Division into experimental groups according to treatment.

\begin{tabular}{|c|c|c|c|}
\hline Group & Rats/box & $\begin{array}{c}\text { Food and water } \\
\text { available }\end{array}$ & Lighting \\
\hline $\begin{array}{l}\text { C } \\
3 C \\
\text { PF } \\
\text { 3PF } \\
\text { BC } \\
\text { BC-PF }\end{array}$ & $\begin{array}{l}1 \\
3 \\
1 \\
3 \\
1 \\
1\end{array}$ & $\begin{array}{l}\text { Ad libitum } \\
\text { Ad libitum } \\
\text { From } 9 \text { a.m. to } 11 \text { a.m. } \neq \\
\text { From } 9 \text { a.m. to } 11 \text { a.m. } \neq \\
\text { Ad libitum } \\
\text { From } 9 \text { a.m. to } 11 \text { a.m. } \neq\end{array}$ & $\begin{array}{l}6 \text { a.m. to } 8 \text { p.m. } \\
6 \text { a.m. to } 8 \text { p.m. } \\
6 \text { a.m. to } 8 \text { p.m. } \\
6 \text { a.m. to } 8 \text { p.m. } \\
\text { Daily } \neq \\
\text { shift }(15 \mathrm{~min})\end{array}$ \\
\hline
\end{tabular}

$\neq$ From day 8 of gestation. 
groups ( $3 \mathrm{C}$ and $3 \mathrm{PF}$ ), the animals were caged by threes from the time of mating, whereas they were caged separately in the other four groups (C, PF, BC, BC-PF). In three groups (C, $3 \mathrm{C}$ and $\mathrm{BC})$ food and water was available ad libitum and in the other three (PF, 3PF and BC-PF) they were given food and water daily during a restricted period $(9 \mathrm{a} . \mathrm{m}$. to $11 \mathrm{a}$ a.m.) from day 8 of gestation. All the animals received $14 \mathrm{~h}$ of light daily. The photoperiod was that of the standard light regime (14L-10D) in four groups (C, 3C, PF, 3PF), but in the other two groups ( $B C$ and BC-PF) the $14 \mathrm{~h}$ of light was shifted daily from day 8 of gestation. To do this, lights-on (dawn) and lights-off (dusk) were advanced 15 min every day. This procedure slightly reduced the darkness period. Light was therefore given to these groups between 2 a.m. and 4 p.m. by day 23 of gestation.

Observations. - Observations were made as previously described (Bosc and Nicolle, 1980a). The animals were checked every $2 \mathrm{~h}$ on days 22 and 23 of gestation, and the births were plotted at 2-hour intervals, the onset of expulsion being the time of delivery. Groups $3 \mathrm{C}$ and $3 \mathrm{PF}$ were monitored with special attention because there were 3 animals per box. The total number and the number of live rats were counted at the end of expulsion, and the live pups were weighed 2 to $6 \mathrm{~h}$ after the end of delivery.

Birth rates on days 22 and 23 of gestation were compared using the nonparametric test of Kolmogoroff Smirnoff (Siegel, 1956). Litter size and stillbirth rates were also analysed by the appropriate parametric tests (Vessereau, 1960).

\section{Results.}

Figure 1 presents the birth distribution observed in the four groups under the standard light regime. In the control group (C) birth distribution was biphasic with the first half occurring on the afternoon of day 22 and the second half on the morning of day 23 of gestation. No parturition was observed during the main part of the night separating these two periods. In group $3 \mathrm{C}$ this pattern was less marked than in group $C(P>0.05)$; fewer births were observed before the night of day 22 (30.8 vs $47.1 \%$ ) or just after dawn on day 23 (51.9 vs $61.8 \%)$. When food and water were restricted to $2 \mathrm{~h}$ in the morning (groups PF and 3PF), the births were clustered into a single period just before and during the first half of the night between days 22 and 23 of gestation. The distributions of these groups (PF and 3PF) did not differ ( $P>0.05)$. A $2 \times 2$ comparison showed that the distribution curves of groups $\mathrm{C}$ and $3 \mathrm{C}$ were different from those of groups $\mathrm{PF}$ and 3PF ( $P<0.05$ or $P<0.01)$.

Grouping did not affect birth time $(P>0.05)$ when groups $3 C$ and $3 P F$ were compared to groups $C$ and $P F$, respectively. However, in groups $3 C$ and $3 P F$ there were three animals per box from mating, and two or three were pregnant. $A$ comparison of groups $3 \mathrm{PF}$ and PF with periodic food presentation showed that deliveries were clustered over a shorter period as the number of pregnant rats per box increased. With ad libitum feeding, a reverse trend was seen (groups $3 \mathrm{C}$ and C). 
Figure 2 compares the two groups under the light shift and the feeding regimes (groups $\mathrm{BC}$ and $\mathrm{BC}-\mathrm{PF}$ ) with the corresponding groups under the standard photoperiod (groups $\mathrm{C}$ and PF). Most births $(82.9 \%$ ) in group BC occurred after dawn of day 23 of gestation. This group differed from groups $C$ $(P<0.05), P F$ and $3 P F(P<0.01)$. When the light shift was associated with a restricted feeding time (group BC-PF), birth distribution was intermediate between those of groups $\mathrm{PF}$ and $\mathrm{BC} ; 61.3 \%$ of deliveries occurred during the night between days 22 and 23 and $32.7 \%$ after dawn on day 23 . This group (BC-PF) differed from groups $P F(P<0.05)$ and $C, 3 P F$ and $B C(P<0.01)$.

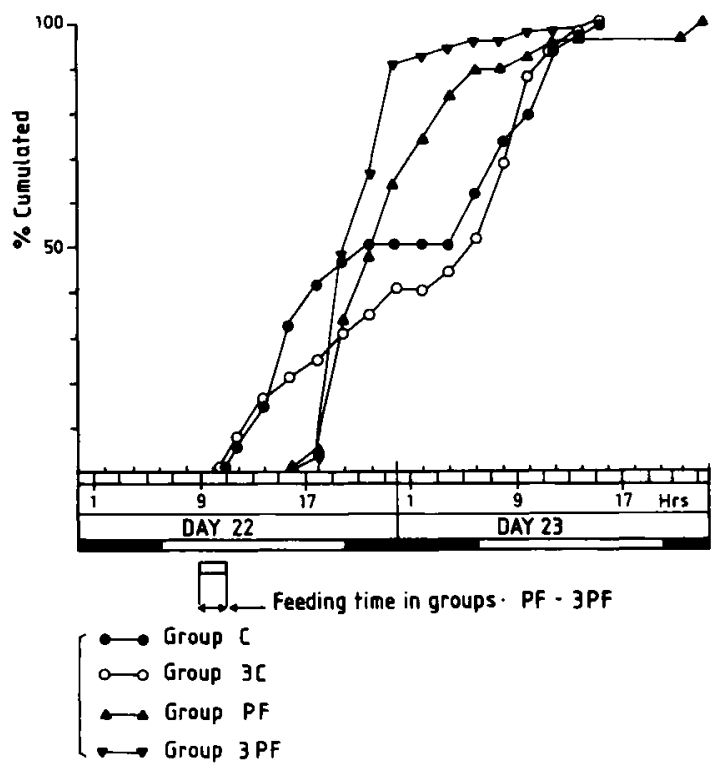

FIG. 1. - Birth distribution on days 22 and 23 of gestation in rats under the standard photoperiod and fed " ad libitum " (groups $\mathrm{C}$ and $3 \mathrm{C}$ ) or with a restricted feeding time (Groups PF and 3PF) from day 8 of gestation. Rats caged alone : groups $\mathrm{C}(\bullet-\bullet ; \mathrm{n}=34)$ and PF $(\boldsymbol{\Delta}-\mathbf{\Delta}$; $n=39)$, or by threes: groups $3 C(0-O ; n=52)$ and $3 P F(\nabla-\nabla ; n=53)$.

When the rats were caged alone, litter size was smaller in group $B C-P F$ than in groups $\mathrm{C}, \mathrm{PF}$ and $\mathrm{BC}$ (mean : 9.0 vs $10.4 ; \mathrm{P}<0.05$ ). When they were caged in threes, it was difficult to determine individual litter size but it was apparently of the same order ( 10.0 and 10.1 for groups $3 \mathrm{C}$ and $3 \mathrm{PF}$, respectively). The stillbirth rate differed among the six groups $(P<0.01$; extremes : $3.4 \%$ for group $3 P F$ and $8.7 \%$ for group $C$ ). However, in groups $C, P F, B C$ and $B C-P F$ the proportions of rats having stillborn young were similar (mean : $30.5 \%$; $P>0.05)$.

Figure 3 shows the variations in the mean birth weight of live pups in groups $C, P F, B C$ and $B C-P F$; fluctuations in birth distribution and litter size did not allow a statistical analysis but the same trend to increased birth weight was observed with longer gestation. In groups submitted to a daily restricted feeding time (PF and BC-PF), mean birth weight was generally lower than in the two groups fed ad libitum (C and $\mathrm{BC}$ ). 


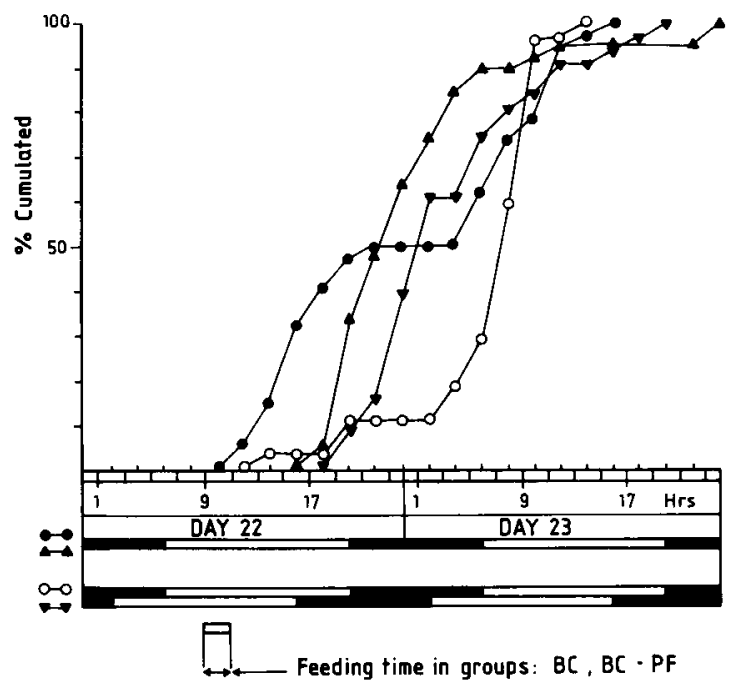

$$
\left[\begin{array}{ll}
\longrightarrow & \text { Group C } \\
\longrightarrow & \text { Group PF } \\
\longrightarrow & \text { Group BC } \\
\text { Group BC - PF }
\end{array}\right.
$$

FIG. 2. - Birth distribution on days 22 and 23 of gestation in rats caged alone and fed " ad libitum " (groups $\mathrm{C}$ and $\mathrm{BC}$ ) or with a restricted feeding time (groups $\mathrm{PF}$ and $\mathrm{BC}-\mathrm{PF}$ ). Rats of groups $\mathrm{C}$ $(\bullet ; \mathrm{n}=34)$ and $\mathrm{PF}(\mathbf{\Lambda}-\mathbf{\Lambda} ; \mathrm{n}=39)$ under the standard photoperiod. Rats of groups BC $(O-O ; n=27)$ and $B C-P F(\nabla-\nabla ; n=31)$ were submitted to a daily shift of light phase from day 8 of gestation. The position of the light phase is shown at days 7 and 23 of gestation.

\section{Discussion.}

The results of this experiment show that birth time in rats can be modulated by biological entrainers such as photoperiod and feeding rhythm and that the actual moment of birth is the result of interactions between these factors. Variations in litter size or stillbirth rate, usually related to the length of gestation or labor, could not explain the difference observed among the groups. The birth weight of live pups was lower in the groups submitted to periodic presentation of food and water than in groups fed ad libitum (fig. 3) ; this was probably the consequence of the reduction of food intake in the dams as observed in nonpregnant females under similar conditions (Krieger, 1974 ; Krieger et al., 1977). As the various treatments applied in this experiment were begun after implantation (Psychoyos, 1973), the influence of photoperiod and feeding rhythm can certainly be attributed to endogenous processes related to the birth mechanism and occurring during the last two-thirds of gestation.

It is now well known that time of birth is photodependent in rats. When they are caged alone and fed ad libitum, there are two periods of delivery, one on day 22 of gestation and another on day 23 ; few or no parturitions occur in between. The relative number of births during these periods and their respective 


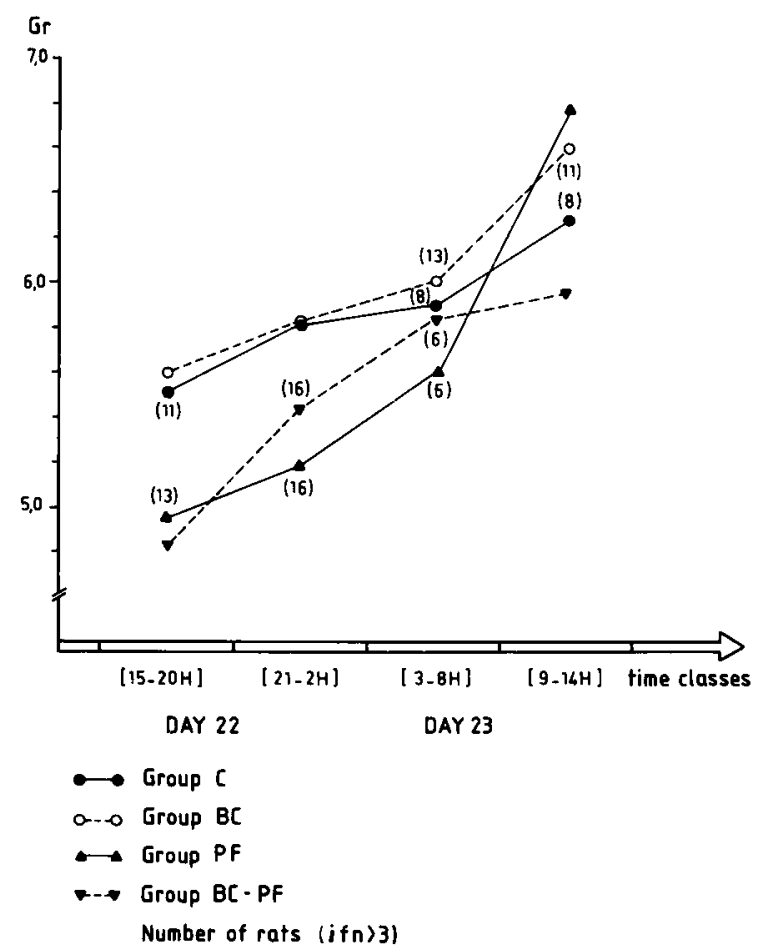

FIG. 3. - Mean birth weight of pups according to length of gestation in the four groups of rats caged alone : groups $\mathrm{C}(\bullet-\bullet)$, PF $(\mathbf{\Delta}-\mathbf{\Delta}), \mathrm{BC}(\cup--())$ and $\mathrm{BC}-\mathrm{PF}(\boldsymbol{\nabla}-\ldots)$. For more details see tigures 1 and 2 (number of rats when $n>3$ ).

positions in each day characterize the photodependent effect (Lincoln and Porter, 1976 ; Bosc, 1981). This is illustrated in the present experiment by the distribution of groups $\mathrm{C}$ and $\mathrm{BC}$ (fig. 2); the progressive backward shift of the light phase applied in group BC caused most of the deliveries to occur after dawn on day 23 of gestation.

The feeding rhythm we imposed during the experiment is a potent modulator of birth time. Under the standard photoperiod, rats fed ad libitum gave birth during the two usual periods when caged alone or by threes. Under the same light regime, rats fed during a restricted time delivered over a single period which began $8 \mathrm{~h}$ after the beginning of feeding (fig. 1). This time-lag was slightly longer than the length of labor (Fuchs, 1969 ; Legrand and Maltier, 1981), suggesting that endogenous endocrine rhythms, entrained by feeding rhythm, are chronologically tied to birth mechanisms in rats.

These facts raise several points of discussion. Is feeding rhythm or related behavior dominant over other biological entrainers which act on birth mechanisms ? Do the effects which have been attributed to photoperiod (Mitchell and Yochim, 1970 ; Plaut et al., 1970 ; Lincoln and Porter, 1976 ; Bosc, 1981) directly depend on photoperiod, or are they indirectly induced by the behavioral rhythms entrained by the light regime? 
The present work provides some answers; it indicates that there is an interaction between the two entrainers concerned here, as illustrated by the shift in birth distribution observed between groups PF, BC-PF and BC (fig. 2). The photodependent effects caused a time-lag in a significant number of deliveries in group BC-PF with respect to group PF ; these two groups had the same feeding regime under two different photoperiods. This photodependent effect was more accentuated in the rats fed ad libitum (group $\mathrm{C}$ vs group $\mathrm{BC}$ ).

Considering the experimental design of this study, we cannot conclude that periodic food presentation was predominant over photic cue in regard to birth time in rats, but we can assume that it is probable for the following reasons. Such predominance of feeding has been established for circadian variations of plasma corticosteroids (Takahashi et al., 1977 ; Krieger and Hauser, 1978) and for locomotor activity (Edmonds and Adler, 1977a, b). Corticosteroids are implicated in the regulation of the length of gestation in rats (Parvez et al., 1972 ; Bosc and Nicolle, 1980a, Klepac, 1981). On the other hand, it is interesting to note that, when food was presented during the light phase, the majority of deliveries took place during the night separating days 22 and 23 of gestation, a period during which there were few or no parturitions in the groups fed ad libitum (figs. 1, 2). If we assume that pregnant rats ted ad libitum consume their food during darkness, as non-pregnant animals usually do, it can be postulated that there is an obligatory shift between the two types of activity : labor and feeding behavior.

The influence of behavior or activity rhythms is also indirectly illustrated by the four groups $C, 3 C, P F$ and $3 P F$ (fig. 1). In groups $3 C$ and $3 P F$ the particular social environment resulted in a non-significant but appreciable modification in the birth distribution of groups $C$ and $P F$; but the effect was reversed by changing food availability (fig. 1). In groups $3 C$ and $3 P F$ the social environment was constituted at mating so the events related to pregnancy and parturition were synchronized. This might explain why the births of group 3PF were clustered in such a short period (fig. 1). Rats show maternal behaviour a few hours before delivery, and this activity depends on preparturient endocrine events (Rosenblatt et al., 1980). By clustering the parturitions and related behavioural events, the feeding rhythm offered possibilities for suckling which probably accelerated the birth process in this group by the release of oxytocin (Fuchs and Poblete, 1970). The mixing of litters, often observed in this particular group (3PF) but rarely in group 3C, supports this interpretation.

The interactions between photoperiod, feeding rhythm and other behavior suggest that photoperiod has a double influence on the time of birth in rats ; it exerts a direct effect on the endogenous endocrine secretions involved in the birth mechanism, and it could also have an indirect effect through its action on rhythms of activity and behavior that are themselves capable of modifying the endocrine secretions controlling birth.

Reçu en décembre 1983.

Accepté en septembre 1984.

Acknowledgements. - The authors wish to thank the Mrs Cahier, Pellan and Vigneau for care of the animals, Ms Ploux for typing the paper, and Dr. G. Martin for correcting the English. 
Résumé. Influence de la photopériode sur le moment de la naissance chez la rate. IV. Effets d'un rythme alimentaire imposé.

Afin d'étudier les effets respectifs de la photopériode et du régime alimentaire sur le moment de la naissance, le début de l'expulsion du fœetus a été déterminé dans six lots expérimentaux de rates. Sous la photopériode standard (lumière de $6 \mathrm{~h}$ à $20 \mathrm{~h} ; 14 \mathrm{~L}-10 \mathrm{D}$ ), les rates, nourries ad libitum, mettent bas au cours de deux périodes préférentielles qu'elles soient isolées (Lot $\mathrm{C}$ ) ou par trois (Lot $3 \mathrm{C}$ ). La première période a été observée en fin de phase claire du $22^{\mathrm{e}}$ jour de la gestation, la $2^{\mathrm{e}}$ en début de phase claire du $23^{\mathrm{e}}$ jour. Sous la même photopériode, les rates nourries, pendant un temps limité (de $9 \mathrm{~h}$ à 11 h) à partir du $8^{\mathrm{e}}$ jour de la gestation (Lots PF et 3PF), ont donné naissance pendant une seule période débutant juste avant et s'étendant sur la 1 re moitié de la nuit séparant les 2 derniers jours de la gestation. Le nombre de rats par cage a affecté légèrement les distributions des naissances et un effet inverse a été observé entre le régime alimentaire et le groupe social constitué à la saillie (Lots $3 \mathrm{C}$ et $3 \mathrm{PF}$ ). La plupart des naissances se sont produites après l'aube du $23^{\circ}$ jour de la gestation lorsque les rates, nourries ad libitum, ont été soumises à une translation progressive de la phase claire (Lot $\mathrm{BC}$ ). Cette translation a été effectuée à partir du $8^{e}$ jour de la gestation en avançant $(15 \mathrm{~min})$ quotidiennement l'aube et le crépuscule. Dans ces conditions, nourrir les rates pendant un temps limité (de $9 \mathrm{~h}$ à $11 \mathrm{~h}$ ) (Lot PF-BC) entraîne une distribution des naissances intermédiaire entre les lots PF et $B C$. Ces résultats indiquent donc que le moment de la naissance de la rate peut être modulé par 2 entraîneurs biologiques : la photopériode et le rythme alimentaire. Ils indiquent aussi, que dans des conditions déterminées, ce moment dépend des interactions dues à ces deux facteurs.

\section{References}

BESCH E. L., 1970. Influence of photoperiod on food and water intake in rats. Aerospace Med., 41. 1145-1148.

BOSC M. J., 1980. Influence de la photopériode ou des conditions de milieu sur la parturition, 179-193. In R. ORTAVANT, A. REINBERG, Rythmes et reproduction. Ed. Masson Paris.

BOSC M. J., 1981. Effects of photoperiod on the time of birth in the rat, 33-50. In Photoperiodism and reproduction. Int. coll. Nouzilly (France). Ed. I.N.R.A. Versailles.

BOSC M. J., NICOLLE A., 1980a. Influence of photoperiod on the time of parturition in the rat. I. Effect of the length of daily illumination on normal or adrenalectomized rats. Reprod. Nutr. Dévelop., 20, 735-745.

BOSC M. J., NICOLLE A., 1980b. Influence of photoperiod on the time of parturition in the rat. 11. Demonstration of a photoinducible phase and determination of some of its characteristics. Reprod. Nutr. Dévelop., 20, 939-948.

BOSC M. J., NICOLLE A., 1982. Influence of photoperiod on the time of birth in the rat. III. Comparison of different daily light lengths with changes in light timing or light pulse during darkness. Reprod. Nutr. Dévelop., 22, 923-930.

DUPOUY J. P., COHEN A., 1975. Comparaison de l'activité corticosurrénalienne fœtale et maternelle au cours du nycthémère et durant la gestation. C. R. Acad. Sci., Paris, sér. D, 280, 463466.

EDMONDS S. C., ADLER N. T., 1977a. Food and light as entrainers of circadian running activity in the rat. Physiol. Behav., 18, 915-919.

EDMONDS S. C., ADLER N. T., 1977b. The multiplicity of biological oscillators in the control of circadian running activity in the rat. Physiol. Behav., 18, 921-930.

FUCHS A. R., 1969. Uterine activity in late pregnancy and during parturition in the rat. Biol. Reprod., 1, 344-353.

FUCHS A. R., POBLETE V. F., 1970. Oxytocin and uterine function in pregnant and parturient rats. Biol. Reprod., 2, 387-400. 
ITOH S., KATSUURA G., HIROT A. R., 1980. Conditioned circadian rhythm of plasma corticosterone in the rat induced by food restriction. Jap. J. Physiol., 30, 365-375.

IXART G., SZAFARCZYK A., BELUGOU J. L., ASSENMACHER I., 1977. Temporal relationships between the diurnal rhythm of hypothalamic corticotrophin releasing factor, pituitary corticotrophin and plasma corticosterone in the rat. J. Endocr., 72, 113-120.

JOHNSON J. T., LEVINE S., 1973. Influence of water deprivation on adrenocortical rhythms. Neuroendocrinologv, 11, 268-273.

KATO M., SAITO M., SUDA M., 1980. Effects of starvation on the circadian adrenocortical rhythm in rats. Endocrinology, 106, 918-921.

KLEPAC R., 1981. Influence of ACTH-secreting tumor $\left(M+T F_{4}\right)$ on fetal rat adrenal gland steroidogenesis in vitro in prolonged pregnancy. Endokrinologie, 77, 192-196.

KRIEGER D. T., 1974. Food and water restriction shifts corticosterone, temperature activity and brain amine periodicity. Endocrinologv, 95, 1195-1201.

KRIEGER D. T., HAUSER M., 1978. Comparison of synchronization of circadian corticosteroid rhythms by photoperiod and food. Proc. nat. Acad. Sci. USA, 75, 1577-1581.

KRIEGER D. T., HAUSER H., KREY L. C., 1977. Suprachiasmatic nuclear lesions do not abolish food shifted circadian adrenal and temperature rhythmicity. Science, 197, 398-399.

LEGRAND C., MALTIER J. P., 1981. Activité électrique de l'utérus chez la rate préparturiente, 61-68. In Cl. BOURY-HEYLER, P. MAULÉON, Y. ROCHET, Utérus et fédoncité. Ed. Masson Paris.

LINCOLN D. W., PORTER D. G., 1976. Timing of the photoperiod and the hour of birth in rats. Nature, 260, 780-781.

MITCHELL J. A., YOCHIM J. M., 1970. Influence of environmental lighting on duration of pregnancy in the rat. Endocrinology, 87, 472-480.

MIYABO S., YANAGISAWA K. I., OOYA E., HISADA T., KISHIDA S., 1980. Ontogeny of circadian corticosterone rhythm in female rats. Effects of periodic maternal deprivation and food restriction. Endocrinology, 106, 636-642.

MOBERG G. P., BELLINGER L. L., MENDEL V. E., 1975. Effect of meal feeding on daily rhythms of plasma corticosterone and growth hormone in the rat. Neuroendocrinology, 19, 160-169.

MORIMOTO Y., OISHI T., ARISUE K., YAMAMURA Y., 1979. Effect of food restriction and its withdrawal on the circadian adrenocortical rhythm in rats under constant dark or constant lighting conditions. Neuroendocrinology, 29, 77-83.

OBLED C., ARNAL M., FAUCONNEAU G., 1975. Synthèse protéique in vivo dans divers tissus du Rat en croissance en fonction du rythme alimentaire. Ann. Biol. anim. Bioch. Biophys., 15, 73-93.

OBLED C., ARNAL M., GRIZARD J., 1977. Influence du comportement alimentaire sur le rythme circadien de la corticostérone plasmatique chez le Rat en croissance. C. R. Acad. Sci. Paris, sér. D, 284, 195-198.

PARVEZ S., PARVEZ H., ROFFI J., 1972. Gestations prolongées chez des rattes traitées par la Métopirone. C. R. Acad. Sci. Paris, sér. D, 274, 262-263.

PECHINOT D., COHEN A., 1983. The determination of maternal and foetal rat plasma corticosterone concentration in late pregnancy by competitive protein binding analysis. J. Steroid Biochem., 18, 601-606.

PLAUT S. M., GROTA L. J., ADER R., GRAHAM Gh. W., 1970. Effects of handling and the lightdark cycle on time of parturition in the rat. Lab. anim. Care, 20, 447-453.

PSYCHOYOS A., 1973. Endocrine control of egg implantation. In Handbook of physiology, Sect. 7, Endocrinology II, Part 2, Chap. 40, 187-215. Amer. physiol. Soc., 1973.

ROSENBLATT J. S., SIEGEL H. I., MAYER A. D., 1979. Progress in the study of maternal behavior in the rat : hormonal, non hormonal, sensory and developmental aspects. $A d v$. Study Behav., 10, 225-311.

SIEGEL S., 1956. In Non parametric statistics for the behavioral sciences. Int. Student, Ed. Mc Graw-Hill Book Comp. Inc., New York.

SZAFARCZYK A., BOISSIN J., ASSENMACHER I., 1971. Effet du niveau d'éclairement sur le rythme circadien de la corticostéronémie chez la Ratte. C. R. Acad. Sci. Paris, sér. D, 273, 2583-2586. 
SZAFARCZYK A., IXART G., MALAVAL F., NOUGUIER-SOULE J., ASSENMACHER I., 1980. Corrélation entre les rythmes circadiens de l'ACTH et de la corticosterone plasmatique et de l'activité motrice évoluant en "libre cours " après énucléation oculaire chez le Rat. $C$. $R$. Acad. Sci. Paris, 290, 587-592.

TAKAHASHI K., INOUE K., KOBAYASHI K., HAYAFUJI C., NAKAMURA Y., TAKAHASHI Y., 1977. Effects of food restrictions on circadian adrenocortical rhythm in rats under constant lighting conditions. Neuroendocrinology, 23, 193-199.

VESSEREAU A., 1960. In Recherche et expérimentation en agriculture, Tome 2. Méthodes statistiques en biologie et en agronomie. Ed. J. B. Baillères et Fils, Paris, p. 539. 